\title{
Neo-liberalism, social democracy or a social market system in South Africa? A Christian-ethical appraisal
}

\author{
Vorster, JM \\ North-West University, Potchefstroom, South Africa \\ koos.vorster@nwu.ac.za
}

\begin{abstract}
Despite the establishment of a full democracy in South Africa 25 years ago, the economy of the country has not answered to the ideals of economic growth and the alleviation of poverty as set by the various parties at the dawn of this new dispensation. Several political administrations have since endeavoured to address the problem with different plans and economic programmes. Characteristic of these plans is the fact that the focus fluctuated between neo-liberal principles and government-regulated social democratic ideas. The programmes reflect the vigorous debate in South African political circles between proponents of the neo-liberal philosophy of the economy and proponents of social democracy. The debated question is: What economic policy will suit South Africa to enable this country to deal with the perennial poverty and inequality in the best way? Should it be mere neo-liberalism or an authoritarian social democratic philosophy? This article aims to introduce a Christian-ethical perspective on the qualities of South African versions of neo-liberalism and socio-democracy in view of the obligation of the markets and the government to pursue the best policy to alleviate poverty and its various social effects. The central theoretical argument of this article is that a Christian-ethical approach holds that the government of the day is responsible to address poverty by applying a policy of economic growth that is immediately effective and sustainable on the long run. This policy entails a strategy that can be termed a "social market economy", which sustains the freedom of the market, but facilitates limited government involvement in the economy on behalf of the poor.
\end{abstract}

\section{Keywords}

neo-liberalism; social democracy; social market system; poverty in South Africa; government involvement; corruption 


\section{Introduction}

Despite the establishment of a full democracy in South Africa 25 years ago, the economy of the country has not answered to the ideals set by the various parties at the dawn of the new dispensation. Progress in prosperity has been recorded in certain sectors of the population, and in this respect, the steady growth of a black middle class is notable. However, the huge historical inequalities between rich and poor persist. What Terreblanche (2002) indicates in his book about the history of inequality in South Africa is still true. Furthermore, poverty and joblessness remain high and it seems that the shortage in adequate housing is not addressed as it should be due to economic restraints and a lack of political will. South Africa is a modern country with a well-developed infrastructure, but with huge inequalities between rich and poor and an alarming rate of joblessness.

The democratic government introduced the Reconstruction and Development Plan (RDP) early on. This programme was followed by the Growth, Employment, and Redistribution Plan (GEAR) and recently the National Development Plan (NDP) (see Breakfast 2015:756). One common characteristic of these plans is the fact that the focus fluctuates between neo-liberal principles and government-regulated social democratic ideas. These programmes reflect the vigorous debate in the South African political circles between proponents of the neo-liberal philosophy of the economy and proponents of social democracy. The debate question is: What economic policy will suit South Africa to enable this country to deal with the perennial poverty and inequality in the best way? Should it be mere neo-liberalism or an authoritarian socio-democratic philosophy?

This article aims to introduce a Christian-ethical perspective on the qualities of the South African versions of neo-liberalism and socio-democracy in view of the obligation of the markets and the government to pursue the best policy to alleviate poverty and its various social effects. This ethical appraisal is done from the perspective of a consequentialist ethics theory (see Vorster 2017:157). The central theoretical argument of this article is that a Christian-ethical approach demands that the government of the day has to address poverty by applying a policy of economic growth that is immediately effective and sustainable in the long run. This policy can be termed a social market economy where freedom of the market is balanced 
with government involvement in the economy on behalf of the poor. To unfurl this argument, the phenomenon of poverty in South Africa in its current form is first illustrated briefly. Secondly, the responsibility of the government to alleviate poverty is assessed from a Christian-ethical point of view. Thirdly, the main characteristics of neo-liberalism as it is presented in South Africa is outlined and evaluated. Fourthly, the main features of the socio-democratic policies in South Africa since 2010 are described and appraised. Lastly, the major Christian-ethical perspectives regarding a market economy and the responsibility of the government are discussed in view of the need for social justice and the alleviation of poverty. This discussion leads to an applicable recommendation.

\section{Poverty in South Africa}

A recent thorough survey of poverty in South Africa in the period 20062015 by Statistics South Africa (2017:14) found that despite the general decline in poverty from 2006 to 2011, poverty levels rose in 2015. "When applying the upper-bound poverty line (R992 per person per month \{pppm\} on 2015 prices), we see that more than one out of two South Africans were poor in 2015 , with a poverty headcount increasing to $55.5 \%$ from a series low of $53.2 \%$ in 2011. This translates into over 30.4 million South Africans living in poverty in 2015. While the recent increase in the headcount is unfortunate, we are still better off compared to the country's poverty situation from a decade earlier when it was estimated that two out of every three people (66.6\% or roughly 31.6 million people) were living below the UBPL in 2006." (Statistics South Africa 2017:14). Despite these minor fluctuations, these findings illustrate that the rate of poverty is extremely high.

The report shares the following findings on individual poverty:

- By 2015, approximately 30.3 million people in South Africa were living below the UBPL - an increase of 3.1 million from 2011.

- Females are still more disadvantaged than males, consistently recording higher headcount, gap and severity measures at each point in time. However, the difference between the sexes is narrowing. 
- Approximately $64.2 \%$ of black Africans were living below the UBPL in 2015. This group has consistently recorded much higher headcount, gap and severity measures than the other population groups.

- The higher poverty gap and severity measures showed that poor people living in rural areas were not only further away from the poverty line on average, but the poorest of the poor in those areas are significantly worse off than their poor counterparts living in urban areas.

- While substantial gains have been made in reducing poverty across all age cohorts between 2006 and 2011, by 2015, poverty had increased for all age groups.

- Levels of poverty differ significantly across provinces, with the Eastern Cape (72.9\%), Limpopo (72.4\%), and KwaZulu-Natal (68.1\%) recording the highest levels of poverty in 2015, while the Western Cape (37.1\%) and Gauteng (33.3\%) had the lowest levels.

- An individual's educational level is closely related to poverty; $79.2 \%$ of individuals with no formal education were poor compared to only $8.4 \%$ of individuals who had a post-matric qualification in 2015 (Statistics South Africa, 2017:69).

The status of household poverty in 2015 was as follows:

- Approximately 6.7 million households in South Africa were living below the UBPL; up from 5.6 million households in 2011.

- Households headed by females remain more disadvantaged than those headed by males, consistently recording higher incidence, a poverty gap and severity measures at each point in time.

- Above $70 \%$ of households headed by individuals with no education were in poverty compared to less than $7 \%$ of households headed by individuals with a higher degree.

- More than three out of every five (65.6\%) rural households were living below the UBPL, which was significantly higher than the approximately one out of every three (29.2\%) households in urban areas (a 36.4 percentage point difference).

- The most populous provinces (Gauteng and KwaZulu-Natal) contributed the largest share to household poverty nationally at $19 \%$ 
and $20.6 \%$, respectively, while the Northern Cape (the least populous province) contributed the lowest share at $2.4 \%$.

- Both child-headed households and those headed by the elderly are still affected more heavily by poverty than the other age cohorts.

- Unlike individual poverty where Indian/Asian-headed households experienced a decline between 2011 and 2015, there was an increase in all the poverty measures (the incidence, poverty gap and severity of poverty) (Statistics South Africa 2017:90).

The above-mentioned statistics indicate that the South African society still has a huge divide between rich and poor and that the levels of poverty are far above the average experienced by economies of the same kind elsewhere. This is the urgency of the situation the present government has to deal with. The argument is taken further in the next section, which offers a Christian perspective on the role a government should play in the alleviation of poverty.

\section{Government and poverty}

Caring for the poor is a very important topic in biblical ethics - both in the Old and New Testaments. This article relies on the main features of the biblical ethics of poverty alleviation to establish what the role of a government and role players such as civil society, the market and the church should be in this respect. An excellent book by De Vaux (1988:73ff) offers a thorough exposition of the position of the poor, the strangers and the slaves in Old Testament times. Bammel's explanation of the "ptogos" in the New Testament is also valuable for a better understanding of the position of the poor as a social class (Bammel 1968:885-915). The results of these studies, as well as the highly informative article of Cachet (1997:215) about the deprived, are used in a summarized form in this exposition.

The poor did not form a separate social class in early biblical society. The early Israelite community in Old Testament times largely enjoyed a good standard of living. The nomadic and semi-nomadic mode of life of the Israelite tribes prior to the conquest knew no sharp or rigid distinction between rich and poor. Members of the tribe had more or less equal rights and statuses as the defenders of the community (Bammel 1968:889). Even then God gave explicit commands in this regard: 
"Exploitation of the poor fellow countryman is forbidden (Ex 22:24). Yahweh is against the oppression of the poor in the courts (Ex 23:6). Already in the fundamental laws, which on the one side, at least for the $7^{\text {th }}$ year, restore the normal state of Yahweh's own exclusive right to the land, and on the other grant lasting protection to the poor, Yahweh, unlike the Greek gods, is the protector of the poor a thought which was to endure throughout the history of Israel" (Bammel, 1968:890).

God announces his judgement on those who exploit the poor (Am 2:6$7 ; 4: 1-3 ; 8: 4-6$ ) (see Kretzschmar 2014:1). Deuteronomy also reflects the social conditions of its period. It promulgates the duty of almsgiving (Dt 15:7-11); says that when a debtor is poor, his security must be given back to him before sunset (Dt 24:12-13), supplementing the law of Exodus 22:25-26; and protects the hired labourer (Dt 24:14-15). In every sabbatical year, the produce of the land was left for the destitute (Ex 23:11) and debts were cancelled (Dt 15:1), "so that there may no longer be any poor man among you" (Dt 15:4). In the Jubilee year a general emancipation had to be proclaimed and every man had to have his ancestral land restored to him ( $\operatorname{Lv}$ 25:10), with the commentaries in the rest of the chapter.

Of course, this does not mean that there were no injustices. This emerges from depictions of the more common experience of life and from the observations of the prophets: there are wicked, impious rich men who oppress the poor, but the poor are beloved by God (Dt 10:18; Pr 22:22-23) and his Anointed will do them justice (Is 11:4).

However, the later economic development of the monarchy created new classes and accentuated social distinctions. This, together with the fact that only landowners had civil rights and that they functioned as the judges, worsened the position of the poor. This means that society came to have a marginalized group made up of the weak, the small men, and the poor, who suffered several burdens. The poor were individuals, and precisely because they were isolated, they were defenceless. By this time, the poor could be regarded as a social class, a minority group in their society, and they were treated by God as such.

The prophets took their cause in hand. Isaiah, for example says: 
"Woe to those who make unjust laws, to those who issue oppressive decrees, to deprive the poor of their rights and withhold justice from the oppressed of my people, making widows their prey and robbing the fatherless."

See in this regard also Isiah $3: 14-15 ; 10: 2 ; 11: 4$, Amos 4:1; 5:12; Psalm $82: 3-4$. The law protected them too. There had been the precepts of Exodus 22:24-26 and 23:6.

God's care for the poor is also explained in the New Testament. Although Jesus refers to the spiritually poor in the Sermon on the Mount (Mt 5:3; Lk 6:20), his special concern for the poor and the downtrodden during the three years of his ministry, indicates his compassion for the plight of minorities. The same concern is discernible in Paul's preaching. He rejects any form of possible social distinction between the rich and the poor in the Christian community (Gal 3:27, Col 3:11). The letter of James contains a running attack on the rich, both inside and outside the Christian community. A reason for this attack on the wealthy is that God has chosen the poor before the world. Has God not chosen those who are poor in the eyes of the world to be rich in faith and to inherit the Kingdom he promised those who love him (Is 2:5)? The New Testament message was indeed directed at the social stratification of the Jewish and Roman communities of that period.

The directives about poverty in the Old Testament were aimed at all the social groups in Jewish society. Caring for the poor was the obligation of the leaders in the political and spiritual realms. The leaders were judged on the way they fulfilled their obligations to the poor and the marginalized, such as the widows and the aliens. In the New Testament Jesus charges people to care for the poor, especially his followers. However, it is fair to say that his teachings also applied to people in leadership positions.

Based on what the Bible teaches about the alleviation of poverty and the stewardship of believers, Boersema (1999:177) summarizes the obligations of Christians regarding political-economic matters as follows:

Are God's laws being obeyed?

Is justice being achieved?

Are the weak adequately protected? 
Is the earth being sufficiently developed to allow mankind to honour God?

Are we being good stewards with God's earth?

More to the point is the view of Naude (2016:225). He designed suitable systematic-theological criteria for judging the economic policies of rulers. He explains that the contribution of the Christian tradition to the discourse is in essence threefold. Firstly, the Christian understanding of human dignity should be translated into political rights such as freedom of speech and socio-economic rights, including the right to food security, shelter, health care, education and employment. Secondly, the Christian tradition should take the perspective of the poor and the suffering as point of departure. The Christian tradition should therefore insist that special economic measures be instituted to care for those who suffer from marginalization, injustice and abuse. This implies forms of redistributive justice that would provide first for the basic necessities of people before it allows exorbitant accumulation of wealth. Thirdly, the Christian tradition should hold the economy responsible for protecting and enhancing the integrity of creation. These general criteria are valuable and can be used effectively in the evaluation of economic policies.

Governments have taken many shapes in the past, starting with the Roman aristocracy. This was followed by the state church, monarchies, the many dictatorships and eventually democracies. In all of these, the citizens had the same expectations founded in their moral convictions. They expected the rulers to be just and mild, reward the good and punish the bad, protect widows and orphans, avoid war, create peaceful institutions, prevent corruption and have a listening ear with respect to the complaints of the people (Stolleis 2008:197). The duty to take care of the poor was, in principle, also carried over to the rulers. It is common knowledge that this duty has been neglected time and again by the rulers of all forms of government. History is full of examples of exploitation of the poor by rulers, sometimes in association with the church. On many occasions the poor and the marginalized revolted only to be oppressed by strict measures. The rise of constitutionalism with its high regard for human rights can largely be ascribed to the historic plight of the poor. It became evident that peace and prosperity will only be achieved if a system of government can 
be designed that can achieve hope and prosperity for all. The constitutional state emerged from the turmoil of the past and with the specific aim to address the circumstances of all citizens.

In South Africa the idea of a constitutional state took root and manifested in the new democracy introduced in 1994. In this form of government, the rulers have to adhere to the ethic of a Bill of Rights founded on the virtues of human dignity, freedom and equality, while being guided by many other principles (Republic of South Africa, 1996; see also Devenish, 1999:11; De Waal, Currie \& Erasmus 2003:6). These values are universal values embedded in natural law. However, there are also pertinent Christian values embedded in the revelation of God in Scripture. What the Bible teaches about people's responsibilities towards the poor and the marginalized is summarized in these values and in the rest of the Bill of Rights. The golden thread of human dignity and humaneness runs through the whole document. In a constitutional state government has a huge responsibility towards the poor. This responsibility is entrenched in the protection of human rights, which is aimed at the development of the wellbeing and prosperity of all the citizens.

A biblical ethic demands that people in power should take care of the poor. This principle should be the main aim of economic policy. The success of the obligations of the government regarding the poor depends on the economic policy chosen by the ruling party. An economic policy must answer to the values of the Bill of Rights. Taking into account the universal values of natural law and the biblical norms regarding the responsibilities of the citizens and the rulers to alleviate poverty and to develop society, the choice for an economic policy should firstly answer the following question: Which policy will be the best to implement in the effort to deal with poverty?

Since 1994 the government of South Africa has chosen and implemented various policies in an attempt to deal with poverty. These policies and systems varied between neo-liberalism and social democracy. How should these policies be appraised from a Christian-ethical point of view taking into account biblical obligation to care for the poor? The following sections debate this question. 


\section{Neo-liberalism}

The term neo-liberalism is used as a description of the philosophy of economy as developed by Friedman (1971:61; 1973:27 \& 1976:42), who became the most politically influential economic theorist of the last quarter of the twentieth century (Küng 1997:188). Neo-liberalism (also defined as "ultra-liberalism" or "neo-capitalism") has many features and the principles are applied in different ways in different environments. However, certain core principles can be identified. These principles include the freedom of individuals to pursue their economic interests; the focus on the free market so that all economic processes are controlled by competition; the state being restricted to national defence and internal order, to guaranteeing the personal protection of its citizens and to creating a stable framework for undisturbed economic development. According to this philosophy, state initiatives in the economy should be limited as far as possible to let the markets control the economy. The philosophy is therefore founded on three important presuppositions: the complete freedom of the individual; the freedom of the markets to control the economy without hindrance; and limitations on the state's ability to interfere in the economic sphere.

The introduction of this economic philosophy in many developed countries over the past four decades led to the privatization of public enterprises. The goal is to create wealth by way of free trade and limited interference by the state. Prices should be determined by the markets. The idea is that the wealth created by the rich should "trickle down" to the poor. In this way social justice could be accomplished. The free flow in the market and the promotion of private enterprises is supposed to create jobs and opportunities for all. The responsibility of the economy towards the poor is therefore to "make more and more profit" (Küng 1997:191).

Such policies were introduced in the UK and the US in the 1980s by Margaret Thatcher and Ronald Reagan respectively. They were both advised by Friedman. Thatcher (1979-1990) limited the excessive influence of the trade unions in the field of wage negotiations and labour conditions, privatized state enterprises, abolished subsidies to private institutions, cut back on the expenditure on the concerns of the often-inflated welfare state and especially the health service, and shaped the tax system in a way that favoured business (Küng 1997:178). Reagan's economic policy incorporated 
important neo-liberal elements such as lower rates of taxation, lower state contributions, a free market instead of state regulation of industry and the stable and controlled growth of the amount of money in circulation (monetarism). The neo-liberalist philosophy also determined the economies of developing countries to a greater or lesser extent since the Thatcher- and Reagan eras. In 1995 Meeks (1995:115) was convinced that the marketdriven economy will stay and will even expand in the foreseeable future.

In 1994 the African National Congress (ANC) became the first postapartheid government. They inherited a highly unequal society with large pockets of poor black communities. Initially the ANC entertained socialist plans for the economy, but they shifted to neo-liberalist ideas on the advice from financial institutions abroad and in South Africa. In an effort to address the poverty, they focussed on social development with the Reconstruction and Development Plan (RDP), which was part of their election manifesto in 1994 (Breakfast 2015:763). The adoption of this policy was accompanied by high hopes of radical changes that would bring about a fundamental transformation of the character of South African capitalism and society (Seekings \& Natrass 2015:8).

This ideal was not realized, and the policy was abolished in 1996. A new policy, named the Growth, Employment and Redistribution Strategy (GEAR), was adopted. Aspects of the neo-liberal theory of economics were introduced with the launch of GEAR (Manuel, 2014:31). Terreblanche (2002:419) called it, "South Africa's version of neo-liberal democratic capitalism.” GEAR implemented more neo-liberal economic principles (Breakfast 2015:764). The programme emphasized trade liberalization, the privatization of state-owned enterprises, fiscal austerity and labour market policy reform in an effort to appeal to investors. Tshitereke (2006:178) remarks: "Despite its weaknesses, GEAR has managed to resuscitate the economy by reducing the fiscal deficit and national debt, bringing down inflation as well as lifting trade barriers, removing tariffs and import duties, and generally winning praise largely from mainstream economists and business interests, for establishing a sound macro-economic base on which future prosperity can be built". However, in the short term there was deindustrialization, falling rates of formal employment and deepening poverty (Seekings \& Natrass 2015:9). The decline was intensified by the global economic crises of 2008. According to Tshitereke, (2006:182) 
GEAR worked for the capital and middle class, but social issues remain contentious. The failure of GEAR, with its neo-liberal foundation, evoked growing protests from the South African Communist Party, labour unions and civil societies in poor communities.

This philosophy undoubtedly resulted in great economic growth in developed countries. The upward curve in the South African economy during the first decade after the introduction of democracy in 1994 can also be attributed to the partial application of this philosophy. However, the question can be asked whether the philosophy really brought immediate relief in developing countries with large-scale poverty. South Africa proves the contrary as the statistics of poverty in the country indicate. Although the economy has grown to some extent, it has not really contributed to poverty alleviation over the last ten years. The biggest problem, namely high unemployment, was not addressed (Seekings \& Natrass 2015:104). Poverty was not alleviated to an extent worth mentioning and unemployment has not decreased. Furthermore, economic inequality prevailed (Davis, 2012:391; Terreblanche 2012:101).

Besides the lack of adequate results from policies based on neo-liberal ideals in South Africa, other fundamental points of criticism against this philosophy of the economy can also be lodged. Looking back at the fruits of neo-liberalism in developed counties since the 1980s, Küng (1997:212) voiced thought provoking criticism against the policies of neo-liberalism. He says that the total market economy easily develops into a kind of a totalitarian system and that all values become subjected to it (see also Snarr 2017:35). The "totalitarian system" leads to a "domesticated" and "depotentiated" ethics, and he is of opinion that:

"a domesticated and depotentiated ethic puts at risk its very own values and criteria; it serves only as a pretext and remains inefficient. And at the same time, as it is already proving to be the case in many areas and regions, a total market economy has devastating consequences: the law, instead of being grounded in universal human dignity, human rights and human responsibilities, can be formulated and manipulated in accordance with economic 'constraints' and group interests; politics capitulates to the market and the lobbying of pressure groups, and global speculation can 
shake national currencies; science delivers itself over to economic interests, and forfeits its function of achieving the most objective and critical control possible; culture deteriorates into being a contributor to the market, and art declines into commerce; ethics is ultimately sacrificed to power and profit, and is replaced by what 'brings success' and 'gives pleasure'; and finally even religion, offered as a commodity on the supermarket of ideas along with much that is para-religious or pseudo-religious, is mixed at will into a syncretistic cocktail for the convenient stilling of a religious thirst which sometimes overtakes even homo oeconomicus."

He also states that in the neo-liberal economies, the "bonum commune", a common good, has no place (Küng 1997:191). This deficiency is illustrated by the inconspicuous status of the plight of the poor in neo-liberal ideals.

This view is dismissed by supporters of neo-liberalism because they feel that businesses have the social responsibility of increasing its profits in order to solve unemployment and alleviate poverty. However, the important question is whether neo-liberalism succeeds in bringing instant social justice to the poor and the marginalized. The slow pace of poverty alleviation in South Africa leads to the conclusion that neo-liberalist policies do not prioritize the fate of the poor. From a Christian-ethical perspective in which the fate of the poor is a fundamental theme, the philosophy of neo-liberalism can be seriously criticized in this respect. Boersema (1999:174) is to the point with his assessment that the free market is not the Christian economic alternative and free enterprise, the market, "must not be baptized with biblical sanction" (Boersema 1999:174). With recognition of the positive things that neo-liberalism establishes, there should rather be a search for a philosophy and policy that brings immediate and direct relief for the poor.

With reference to the prevailing social injustices, inequality and poverty in South Africa, Terreblanche (2002:439) makes an appeal for a paradigm shift towards a philosophy of social democracy. To some extent there has been such a shift in the form of new policies in South Africa. How did these policies affect the plight of the poor? The next section attends to this question. 


\section{Social democracy}

The concept social democracy is, in the words of Seekings and Natrass (2015:16), a highly heterogeneous concept. They argue that the notion can include a wide variety of ideas related to the relationship between the state and the economy.

"It embraces any position that advocates interventions in the market economy to reduce inequality and promote social justice whilst working through the institutions of representative democracy and rejecting revolutionary strategies" (Seekings \& Natrass 2015:16).

Moene and Wallerstein (1995:186) define the concept as

"a distinctive set of institutions and policies that fit together and worked relatively efficiently to reduce both the insecurity and the inequality of income without large sacrifices in terms of economic growth or macro-economic instability".

This "distinctive set of institutions and principles" can include:

"a welfare state, Keynesian macroeconomic policies, a commitment to full employment, and advanced social policies; bi- or tripartite bargaining over wages and conditions of employment, at national or sectoral levels; close links between the social democratic party, trade unions, and associated organizations in civil society, each organized in characteristic ways; and a support base comprising primarily the industrial and urban working classes" (Seekings \& Natrass 2015:16).

Adding to this viewpoint of Seekings and Natrass, it can be said that the concept "social democracy" can also include the notion of a "developmental state" in all its different manifestations as described by Burger (2014:160). These may be "a social investment state" or a "transfer welfare state". Although these terms have differences and accentuations, they all subscribe to the idea of a state where the government plays a large, active and significant role in the economy, but they support selected, mostly private enterprises.

According to Burger (2014:161) the key concepts of such a model are the following: 
- A singular focus on economic growth as the prime directive of the economy and society. Growth provides the legitimacy of the system.

- A state-led industrial policy with the government actively supporting selected industries.

- A professional bureaucracy that is highly capable and well connected to industry.

- A labour market and an education system that are subjected to the singular focus on growth.

- An authoritarian regime intent on maintaining stability so as not to undermine economic growth. Establishing a very high savings rate that can be used for investment and capital deepening.

- Establishing an export-led growth model.

In the first decade of the twentieth century, the government of South Africa shifted its policy to a democratic distributional policy that complies with most of these ideas. This policy can also be labelled social democracy according to Seekings and Natrass (2015:16 \&18). In the South African context at that point of time, it meant no privatization and more governmental interference in the economic process, as well as growing direct care to the poor by way of state grants. The government designed a new economic programme in 2012 founded on the idea of a developmental state - a state that prioritizes development (Republic of South Africa, 2012:26; Breakfast 2015:769). Burger (2013:160) defines a developmental state as follows:

"A developmental state would be a state where the government plays a large, active and significant role in the economy, but in support of some selected, mostly private industries".

This plan was called the National Development Plan (NDP) (Republic of South Africa, 2012) and it aimed to regulate market forces, create jobs and reduce the disparities between the rich and the poor. It rendered public education and health care more accessible and allocated public funding in pro-poor ways. Housing, infrastructural development and municipal services were directed towards the poor. Pensions and other grants were financed out of taxation and social insurance was expanded. The ruling ANC was deeply involved in organized labour by way of its coalition with 
COSATU, the powerful trade movement. These policies, rather than neoliberal ideas, were highlighted in the Zuma administration since 2009 and were formalized in 2012 .

Despite these noble ideals, poverty and unemployment prevails. This is evident from the statistics mentioned earlier in this article. Just like with the initial neo-liberal approach, the implementation of essential social democratic ideas did not really relieve the plight of the poor in South Africa. During the Zuma administration (2009-2018), joblessness grew at alarming levels and the growth rate of the economy declined significantly. In spite of the new plan, the economy remained in a state of disrepair, partly because the plan has not been implemented effectively as a result of incompetent management and the absence of a professional bureaucracy that is capable and connected to industry. Although the country experienced slight economic growth, the growth is not sufficient to curb the waves of joblessness and extreme poverty.

The phase 2010-2018 will indeed be remembered as an era where corruption in the public sector escalated (see Public Protector of South Africa, 2016). Martin and Solomon (2016:31) found in their research that corruption has become institutionalized within the ANC, with the president, Jacob Zuma, taking the lead. They report that the institutionalization of corruption was reflected in the fact that Zuma has appointed some of his most loyal accomplices in strategic state institutions with the aim of suppressing their independence. The Premier League, as it is commonly referred to, supported the Zuma values in exchange for Zuma's support, and has in turn mismanaged state resources. The president had a deviant relationship with the Gupta family. The presence of the Guptas and their close relationship with President Zuma were highlighted in the report of the Public Protector (2016) with great discontent. It has become evident that this family has systematically benefited from Jacob Zuma's rule. Their own private interests significantly influenced the state's decision-making processes. This point speaks directly to the following incidents: appointing Zwane as the Minister of Mineral Resources; dismissing Nene and strategically replacing him with van Rooyen; and promising cabinet positions to other individuals in the administration. The Guptas thus emerged as one of the latest capitalist oligarchies seeking to capture tenders in the state, especially 
in state-owned enterprises in the country. Behaviours such as cronyism and greed have trickled down to the municipal level. The phenomenon of institutionalized corruption as exposed by Martin and Solomon has inhibited the implementation of the noble ideals of the NDP.

Furthermore, the current dilapidated condition of the state-owned enterprises in South Africa proves that the government does not have the capability and expertise to manage large corporations. This fact is indeed a worldwide phenomenon. Private enterprises have been nationalized all over the world with the aim of creating employment and alleviating poverty. However, socialist economies worldwide have failed dismally over the last five decades. Up to this point in time South Africa's version of social democracy has not delivered the goods when judged from the perspective of poverty alleviation and justice - the essential normative condition advocated by a Christian-ethical appraisal of the success of an economic system.

Neither the application of neo-liberal principles nor social democratic ideas has addressed the perennial poverty in South Africa satisfactorily. Neo-liberalism lacked a clear vision of the prerequisite of poverty alleviation as part of economic policy and social democracy was inhibited by incompetent governmental institutions and corruption. A policy should be developed that can overcome the limitations of these two approaches. The following evaluation aims to contribute to such a development from a Christian-ethical perspective.

\section{Evaluation}

The Bible and the Christian ethic do not provide a blueprint for economic policies. Neither neo-liberalism nor social democracy can be seen as typical Christian models for economic policies. The main Christian principle regarding economic policy is that social justice must be served. The economy has to improve the lives of the poor. It must have a social conscience. Market, state and civil society should be led by this important biblical principle.

To my mind, this purpose can be served by what Boersema (1999:173) calls "a conditional preference for the market". His view, with certain 
alterations and additions, can be employed to develop a responsible and workable economic policy for South Africa. This view can be enunciated in the following statements:

- First of all, the market is not a perfect means to accomplish the goal of social justice. Depending on social conditions and context, it may need various forms of regulation. South Africa has a unique history where the policies of the past resulted in severe inequality (Terreblanche 2002:391). This inequality cannot be corrected by the markets alone. It needs active government involvement. Therefore, the choice can be for a market economy with a certain extent of regulation by the rulers of the day. However, the extent of such involvement should be clearly delineated. Arguments pertaining to such a delimitation continue in subsequent paragraphs.

- The market must not be baptized with biblical sanction but should be seen as a means to achieve biblical goals. The markets should not be idolized as the end in itself, but as a means to the end of social justice. As a means to an end, the following positives can be identified from a Christian-ethical perspective: the market allows for the maximum scope of personal responsibility and involvement in the alleviation of poverty and job creation. It provides maximum incentive for people to obey the biblical command to work. It makes available the space and opportunities for Christians to employ their entrepreneurial skills and gifts, to invest and to be personally involved in the economy by directly creating jobs, and by generating the resources necessary to provide assistance to the poor and the helpless. Too much state control and social engineering inhibit this personal responsibility and involvement and the opportunity for individual investors to create wealth at the grassroots level of society.

- A point of criticism that can be raised against the market is that it is essentially guided by self-interest. The self-interest of the investor or the entrepreneur is the fuel that gets the market economy growing. Boersema (1999:173) maintains that this fact is not a reason why the market economy should be rejected out of principle. Self-interest cannot simply be equated with selfishness and greed. He proposes that where selfishness and greed cause the market to yield results inconsistent with Christian-ethical principles, controls are required. 
In my opinion, the idea of self-interest as the motivation for marketdriven economic growth can be questioned from a Christian-ethical perspective. In a previous study I have argued on the foundation of Ph. 2:5-7 that the attitude of Christians should rather be the attitude of servanthood and stewardship and in this respect the interest of society at large and especially the poor should be the guide of the market economy (see Vorster 2007:153). Christians partaking in the market economy should pursue common interests and not selfinterest.

- In addition to what Boersema (1999:173) discusses above, another significant observation about the market economy is the fact that neo-liberalism assumes value neutrality. Rothchild (2005:123) says: "Dominant economic models envisage themselves as valueneutral enterprises that rely on expedient market mechanisms and consistently rationally self-interest choices". This assumption in modern economics can be questioned from the premise that no corporation can claim value neutrality. Kouwenhoven (1986:124) explains that every corporation is embedded in a certain social order with a certain value system and in a power system that can open and close markets and that provides the legal framework for the corporation to function in. They can operate with sound values or bad values, but not without any values. A corporation does not develop in a void. Already at its planning stage a corporation is value-driven, and these values stem from the society of its birth. The corporation is deeply intertwined with other spheres in society. Consequently, in addition to what is expressed in the previous paragraph, it can be said that it is the duty of Christians in civil society to translate Christianethical norms into economic values for implementation in corporate enterprises. They should promote the idea of a "code of conduct" in corporations, where the responsibility of social justice and the protection of the environment are adequately addressed.

- What is the role of the government? Government has the responsibility to maintain the justice system and, in particular, to ensure that justice is done to the weak (Boersema 1999:174). A legal framework must be developed and maintained to permit the operation of the economy, without which the market cannot operate. 
A professional bureaucracy that is highly capable and well connected to industry must be established. The government's involvement with the market should also be guided by the idea of the common good, social justice and the protection of the environment. This:

“... may involve the organization of society in such a way that people do not become impoverished. It may include combatting unemployment and it may include direct support to those who need it - although, as much as possible, incentives should be retained for the weak to exercise their own responsibility." (Boersema, 1999:175).

Taking into account this principle about government involvement, it can be said that the economic policies in South Africa were on the right track at least in principle, but that the execution was heavily flawed due to lack of political will, a poorly developed bureaucracy, state capture and severe corruption in the public sector.

- To avoid the government's failure in exercising social justice, as is the case in South Africa, another Christian-ethical principle regarding the responsibility of government is important. Boersema (1999:175) describes this principle as follows:

"The sinfulness of man implies that the role of the government should be limited. The fact that, like all of us, the government officials are sinful, should lead us to avoid concentrating too much power in their hands. Moreover, excessive government is likely to tempt people to tax evasion, non-compliance of laws, corruption and other sinful acts."

When framing economic policies and their execution in South Africa, economists must define the fine line between freedom of the market and the limitation of government involvement in order to promote social justice and to avoid state capture and corruption in the public sector.

Up to now these principles have not been implemented effectively in the South African economy and it is up to Christians and others with likeminded ideas to promote these ideas in the social and public sphere. 


\section{Conclusion: a social market economy?}

Pure neo-liberalism and the South African version of social democracy displayed severe deficiencies. An alternative should be developed. From a Christian-ethical perspective one can conclude that a market-driven economy where the government is to a limited extent involved on behalf of the poor, seems to be the best option for South Africa today. The government has to introduce incentives for the poor, reduce unemployment, develop a legal system conducive to social justice and a professional bureaucracy that is highly capable and well connected to industry. At the same time the private sector must be permitted the freedom to participate in the market without unnecessary limitations. Küng (1997:196) defines such an economic policy as a social market economy. This may be the way ahead.

\section{Works consulted}

Bammel, E 1968. "Ptogos”, in Friedrich, G., (ed.), Theological dictionary of the New Testament. Eerdmans, Grand Rapids, Michigan, vol. VI, pp. 885-915.

Boersema, J 1999. Political-economic activity to the honour of God.

Premier, Winnipeg.

Breakfast, N 2015. 'The effect of macro-economic policies on sustainable development in South Africa: 1994-2014', Journal of Public Administration, 50(2), 756-774.

Burger, P 2014. "Facing the conundrum: How useful is the

'Developmental State' concept in South Africa?" South African Journal of Economics, 82(2), 159-180.

Davis, R 2012. “Afrikaner capital elites, neo-liberalism and economic transformation in post-Apartheid South Africa", African Studies, 71(3), 391-407.

De Vaux, R 1988. Ancient Israel. Its life and institutions. Darton, Longman \& Todd, London.

De Waal, J, Currie, I \& Erasmus, G 2003. The bill of rights handbook. Juta, Landsdowne. 
Devenish, GE 1999. A commentary of the South African bill of rights. Butterworths, Durban.

Friedman, M 1971, A theoretical framework for monetary analysis. National Bureau of Economic Research, New York.

Friedman, M 1973. Money and economic development. The Horowitz lectures of 1972. Praeger, New York.

Friedman, M 1976. Milton Friedman in South Africa. His visit to the Graduate School of Business, University of Cape Town. March-April 1976. UCT, Cape Town.

Kouwenhoven, A 1986. Inleiding in de Economische Ethiek. Callenbach, Nijkerk.

Kretzschmar, L 2014. "An ethical analysis of the implementation of poverty reduction policies in South Africa and Chile and their implications for the Church", HTS Theological Studies/Theological Studies 70(1), art\#2069, 11 pages, http//dx doi org/10.4102hts v70i1.2069

Küng, H 1997. A global ethic for global politics and economics. SCM Press, London.

Lion Cachet, FN 1997. “Die Diens aan die agtergeblewenes. 'n Perspektief op die wette van ou Israel/Helping the deprived - A perspective on the laws of Israel”, In die Skriflig/In Luce Verbi, 31, 215-228.

Martin, ME \& Solomon, H 2016. "Understanding the phenomenon of 'State capture' in South Africa", Southern African Peace and Security Studies, 5(1), 21-34.

Meeks, MD 1995. "God's Oikonomia and the new world economy", in Stackhouse ML, Berger, PL McCann, DP \& Meeks, MD (eds.), Christian social ethics in a global era. Abingdon, Nashville, pp. 111-126,

Moene, KO \& Wallerstein, M 1995. "How social democracy worked: Labour-market institutions”, Politics and Society, 23(2),185-211.

Naude, P 2016. Pathways in Ethics. Justice, interpretation, discourse, economics. Sun Press, Cape Town. 
Public Protector of South Africa, 2016. State capture Report NO:2016/17, Public Protector of South Africa, Pretoria, www.publicprotector.org Republic of South Africa, 1996. Constitution of the Republic of South Africa, Law 108 of 1996, Government of the Republic of South Africa, Pretoria.

Republic of South Africa, 2012. National Development Plan 2030. Our future, make it work, National Planning Commission, Pretoria.

Rothchild, J 2005. "Ethics, law and economics: Legal regulation and corporate responsibility", Journal of the Society of Christian Ethics, 25(1), 123-146.

Seekings, J \& Nattrass, N 2015. Policy, politics and poverty in South Africa, UNRISC, Macmillan, Hampshire.

Snarr, CM 2017. "Remembering the poor: Interfaith collaboration, neoliberalism and anti-imperial gospel”, Journal of the Society of Christian Ethics, 37(1), 24-44.

Statistics South Africa, 2017. Poverty trends in South Africa. The examination of absolute poverty between 2006 and 2015, Report No 03-10-06, Statistics South Africa, Pretoria.

Stolleis, M 2008. "State Ethics”, in Fahlbusch, E; Lochman, M; Mbiti, J; Pelican, J \& Vischer, L (eds). The encyclopedia of Christianity. Brill, Leiden/ Eerdmans, Grand Rapids, vol. 5, pp. 193-198.

Terreblanche, S 2012. Lost in transformation. South Africa's search for a new future since 1986, KMM Review, Johannesburg.

Terreblanche, S 2002, A history of inequality in South Africa 1652-2002. University of Natal Press, Pietermaritzburg.

Tshitereke, C 2006. The experience of economic redistribution. The Growth, Employment and Redistribution Strategy in South Africa. Routlegde, London.

Vorster, JM 2007. Christian attitude in the South African Liberal

Democracy. Potchefstroom Theological Publications, Potchefstroom. 
Vorster, JM 2017. Ethical perspectives on human rights. Potchefstroom Theological Publications, Potchefstroom. 